AGRICULTURE AND BIOLOGY JOURNAL OF NORTH AMERICA

ISSN Print: 2151-7517, ISSN Online: 2151-7525, doi:10.5251/abjna.2010.1.5.791.795

(C) 2010, ScienceHu $\beta$, http://www.scihub.org/ABJNA

\title{
Dietary dried Kigelia africana fruits meal as fertility enhancer in female Clarias gariepinus (Burchell, 1822)
}

\author{
A.A Dada, E.O Adeparusi and O.V Alale \\ Department of Fisheries and Aquaculture Technology \\ Federal University of Technology, PMB 704, Akure, Ondo State, Nigeria \\ Tel:+2348054504173 E-mail: dadaayokanmi@yahoo.com \\ ABSTRACT
}

The pro-fertility effect of dried $K$. africana fruit meal was investigated on reproductive performance of female C. gariepinus (mean body weight, 396.05 \pm 7.04 ) fed with increasing levels for 90 days in relationship to egg production and quality (number, shape, structure, fecundity) and hatchability (\% fertilization, \% hatching, \% survival). Fecundity dropped from 93345 in fish fed with the control diet to 59904 in fish fed with dried K. africana fruit meal. Fertilization of the eggs decreased with increasing dietary KAFM levels. Also \% deformity decreased from $3.62 \%$ in fish fed with control diet to $0.95 \%$ in fish fed with dietary KAFM. Hatchability (\%) increased from $75 \%$ in fish fed with the control to $88.98 \%$ in fish fed with diet D3 (100 g KAFM/kg diet) but decreased with increasing dietary KAFM levels to 150 and $200 \mathrm{~g} / \mathrm{kg}$ diet. The decreased in \% deformity in hatchlings of $C$. gariepinus fed dietary KAFM compared with the control diet suggest that $K$. Africana fruit meal improves the quality of larvae. The highest \% survival $(92.84 \%)$ of hatchlings was recorded in fish fed with dietary KAFM (100 g KAFM/kg diet). Egg sizes for fish fed the control diet and dietary KAFM levels revealed no significant difference in egg size. The results showed that the dried $K$. africana fruit meal had greater fertility on male than female $C$. gariepinus.

Keywords: Kigelia africana, egg quality, fertility, Clarias gariepinus.

\section{INTRODUCTION}

Aquaculture is a fast growing sector in Nigeria contributing less than $5 \%$ of the total fish supply but at a growth rate of about $2 \%$ per year (Moses, 2006). In fish reproduction under controlled conditions, attempts are made to obtain sperm of the highest quality and hence to produce the highest possible numbers of good quality seeds. Several factors that affect fish seeds quality includes different strains, genetics, nutrition, content of feed and activities of modern agriculture which have introduced several substances such as organic matter, chemical fertilizer and insecticides into the water used for cultured medium (Canyurt and Akhan, 2008). Common practices in hatcheries such as transportation, handling, cleaning, crowding, use of chemicals, and problems with water quality are stressors that may negatively influence reproduction (Billard et al 1995).These factors affect fertilization success in artificial reproduction commonly used for aquaculture species. As a result, low quality fish seeds are produced.

The need for high quality fish seed has necessitated research into various ways of enhancing fertility to meet the growing demand. However the continuing expansion of aquaculture requires shifting from synthetic drugs to natural plant. Medicinal plants that were once considered of no value are now being investigated, evaluated and developed into drugs with little or no side effects on the organisms (Adedeji et al.2006b). The use of medicinal plants as fertility enhancer in aquaculture has now being receiving some attention. Dada and Ajilore (2009) used extract of $G$. kola seed to enhance fertility in C. gariepinus while Adeparusi et al. (2010) used dried K. Africana fruit meal to enhance fertility in male $C$. gariepinus.

Kigelia africana (Lam) Benth, which belongs to the family bignoniaceae is abundant in the tropics and widely used in southern Nigeria as a herbal remedy for various ailments such as diarrhea, malaria, rheumatism, retained placenta and dizziness (Gill 1992). Sexual complaints such as infertility, poor libido, sexual asthenia and impotence are treated with medicines containing the fruits, roots or leaves of K. africana (Owolabi and Omogbai 2007). K. africana fruit extracts had been successfully used as fertility enhancing agent in rats (Abioye et al. 2003). It is therefore not out of place to expect a similar effect on fish. This method of enhancing fertility in fish could be easier to adopt by poor fish farmers since $K$. africana fruits are available all year round in the tropics and sub-tropical regions. Phytochemical screening of $K$. africana showed the presence of steroid (Stahl 1988). 
The objective of this study was to investigate the effects of varying dietary supplementation of $K$. africana on the egg quality and fertility in $C$. gariepinus.

\section{MATERIALS AND METHODS}

The experiment was carried out in the research farm of the Department of Fisheries and Aquaculture Technology, Federal University of Technology, Akure, Ondo State, Nigeria. The experiment consisted of five treatments with each representing different inclusion level of dried $K$. africana fruit meal. These treatments have three replicates each. The graded level of $\mathrm{K}$. africana fruit meal used were 0.00 $\mathrm{mg} / \mathrm{kg}$ feed, $50 \mathrm{~g} / \mathrm{kg}$ feed, $100 \mathrm{~g} / \mathrm{kg}$ feed, $150 \mathrm{~g} / \mathrm{kg}$ feed and $200 \mathrm{~g} / \mathrm{kg}$ feed in the treatment respectively. Formulation of Experimental Diets: Fruits of the $K$. africana were collected from Ilale Keji, Village, Owo Local Government area, Ondo State, Nigeria and identified at the department of Forestry and Wood Technology, Federal University of technology, Akure. After collection, the fruits were cut into small pieces and sun dried. The sun dried fruit was grounded into fine powder and analysed for crude protein, fat, moisture, ash, crude fiber using (AOAC 1997). 50, 100,150 and $200 \mathrm{~g} / \mathrm{kg} \mathrm{K}$. africana were measured out and mixed with basal feed of $40 \%$ crude protein based on the formulation defined for African catfish C. gariepinus (Fagbenro and Adebayo, 2005).

Five isonitrogenous diets were formulated from practical ingredients (Table1) where the control basal diet was without $K$. africana fruit meal and the other diets were supplemented by 500,100, 150 and 200 $\mathrm{g} / \mathrm{kg}$ of $K$. africana fruit meal respectively. The experimental diets were formulated to contain almost $40 \%$ crude protein. Proximate composition of diet was carried out as described by AOAC (1997) (Table 1).

All dietary ingredients were weighed with a weighing top load balance (Metler Toledo, PB 8001 London). The ingredients were ground to a small particle size. Ingredients including vitamin premix and $K$. africana meal were thoroughly mixed in a Hobbart A- 2007 pelleting and mixing machine (Hobart Ltd London, England) to obtain a homogenous mass, cassava starch was added as a binder. The resultant mash was then pressed without steam through a mixer with $0.9 \mathrm{~mm}$ die attached to the Hobart pelleting machine. The produced pellets were dried at room temperature and kept frozen until experimental start.
Collection and Acclimatization of Experimental Fish: Experimental broodstock (mean weight, $396.05 \pm 7.04)$ were sourced from Agriculture Development Project (ADP), Akure. The broodstocks were conditioned for two weeks in concrete holding tanks at the department of Fisheries and aquacuture technology fish farm, Federal University of Technology, Akure. During this period they were fed with commercial diets of $40 \%$ crude protein twice daily at $3 \%$ of their body weight.

Experimental design: Water was sourced from an adjacent fish pond using 1.5HP pump and the tanks were filled to a depth of $0.6 \mathrm{~m}$. 8 female C. gariepinus broodstock were stocked into each tank, with three replications per treatment. The diets were assigned randomly to the tanks and each group of fish was fed at $3 \%$ body weight/day in two equal portions at $900-$ 1000 hours and 1600-1700 hours for 90 days. All fish were removed from each concrete tank every week and batch-weighed.

Reproductive performance: At the end of the feeding trials, six females randomly selected per dietary treatment were weighed, killed and dissected to remove the ovaries. Fecundity estimation was done using gravimetric sub-sampling (wet method) as described by Bagenal (1978). The ovaries were carefully weighed after removing excess water on filter paper and counted the number of eggs per I $\mathrm{g}$ and then calculated the total number of eggs. The total number of eggs per ovary was derived by multiplication by the factor; total weight/10 g. Six fresh eggs were randomly selected per dietary treatment were used for egg diameter $(\mathrm{mm})$ measurement. For the pear-shaped eggs, the mean diameter of the long and short axes was taken as the diameter of the oocyte (Ayinla and Akande, 1988). Data on egg diameter in conjuction with the Percentage fertilization and percentage egg hatching were used to assess the egg quality.

Determination of fertilization rate: For calculating percentage fertilization, a sample of about 30 eggs from each replicate of each treatment were carefully taken on Petri dish and $0.1 \mathrm{ml}$ of milt was measured in $(\mathrm{ml})$ with a plastic syringe and used to fertilize each replicate of the treatment and the number of fertilized and unfertilized eggs were counted under a microscope (40 times magnification). The percentage of egg fertilized as well as the percentage number of egg hatched and percentage survival were computed according to the method described by Ayinla and Akande (1988): 
$\%$ Egg fertilized $=\frac{\text { Number of eggs incubated }- \text { number of opaque eggs }}{\text { Total number of eggs incubated }} \times 100$

$\%$ Hatchabili ty $=\frac{\text { Number of whitish broken eggs }}{\text { Total number of hatchlings }} \times 100$

$\%$ Survival $=\frac{\text { Number of hatchlings alive up to larvae stage }}{\text { Total number of hatchlings }} \times 100$

$\%$ Deformed larvae $=\frac{\text { Number of deformed larvae }}{\text { Total number of larvae }} \times 100$

Water quality parameters: Water quality parameters such as temperature, $\mathrm{pH}$ and dissolved oxygen concentration were monitored weekly throughout the study using mercury-in-glass thermometer, $\mathrm{pH}$ meter (Hanna H198106 model) and dissolved oxygen meter (JPP-607 model) as described by APHA (1987).

Statistical analysis: The values are recorded as mean \pm standard deviation. The statistical significance of difference in the mean and standard deviation $(P<0.05)$ was analyzed by one-way ANOVA test comparison of each of the test groups and the control using the SPSS 15. Duncan's multiple range was used to compare differences among individual means (Zar, 1996). Differences were considered significant at $p$ levels $<0.05$.

Table1. Ingredient and proximate* composition of experimental diets

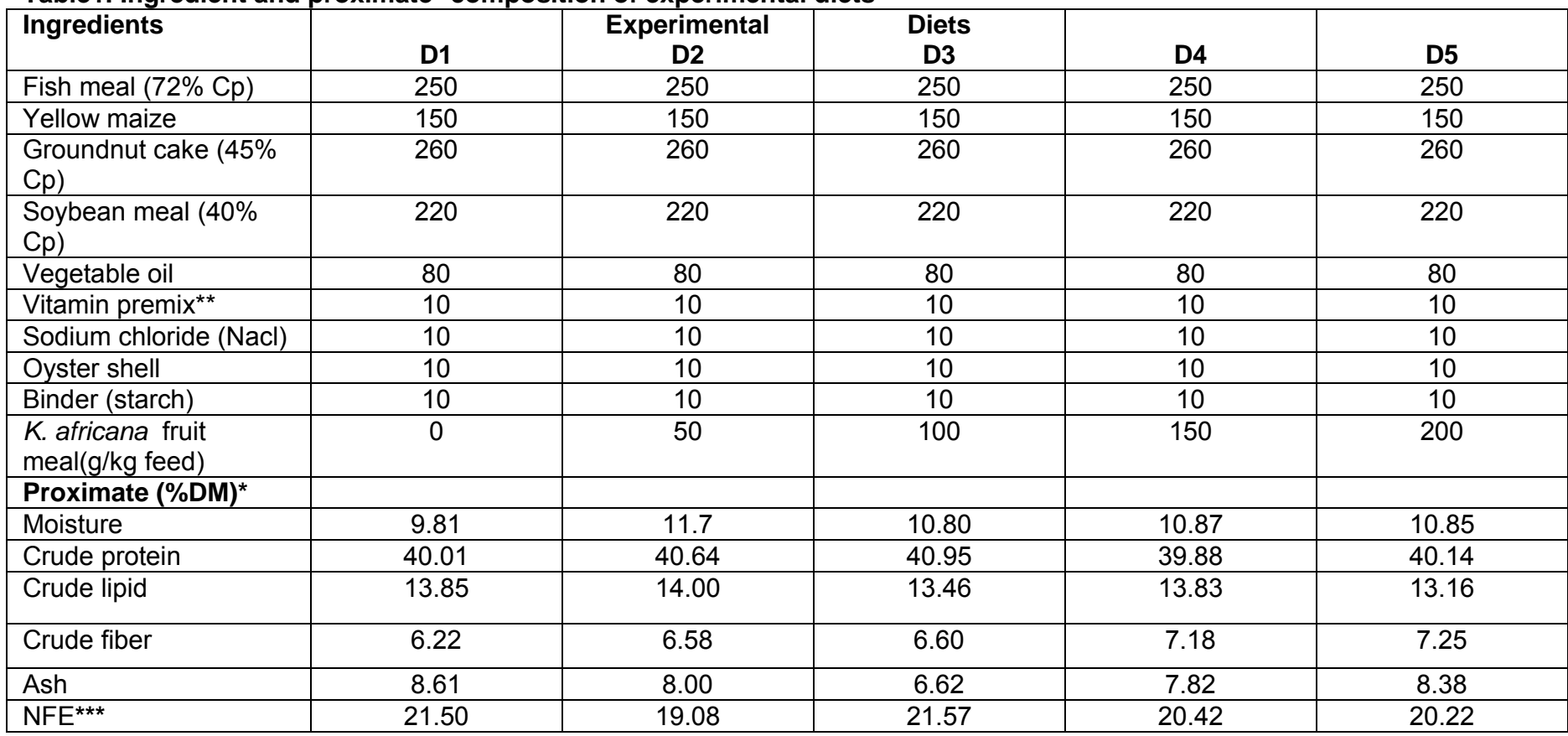

*Determined using standard methods (AOAC 1997). All samples were analysed in triplicates.

**Vitamin premix - A Pfizer livestock product containing the following per $\mathrm{kg}$ of feed: $A=4500 \mathrm{I} . \mathrm{U}, \mathrm{D}=11252 \mathrm{I} . \mathrm{U}, \mathrm{E}=$

$71 \mathrm{I} . \mathrm{U}, \mathrm{K}_{3}=2 \mathrm{mg}, \mathrm{B}_{12}=0.015 \mathrm{mg}$, panthothenic acid $=5 \mathrm{mg}$, nicotinic acid $=14 \mathrm{mg}$, folic acid $=0.4 \mathrm{mg}$, biotin $=0.04$

$\mathrm{mg}$, choline $=150 \mathrm{mg}$, cobalt $=0.2 \mathrm{mg}$, copper $=4.5 \mathrm{mg}$, iron $=21 \mathrm{mg}$, manganese $=20 \mathrm{mg}$, iodine $=0.6 \mathrm{mg}$,

selenium $=2.2 \mathrm{mg}$, zinc $=20 \mathrm{mg}$, antioxidant $=2 \mathrm{mg}$

${ }^{* *}$ NFE $=$ Nitrogen - free Extract $=100-($ Crude protein + Crude fiber + Lipid content + Moisture content + Ash $)$

\section{RESULTS}

The effects of different concentrations of dietary $K$. africana on the reproductive performance of $C$. gariepinus broodstock fed for 90 days were presented in Table 2 . The mean egg weight ranged from $64.25 \mathrm{~g}$ to $99.30 \mathrm{~g}$ with the control diet having the highest mean value. Mean egg weight of the fish on the control diet was significantly $(P<0.05)$ different from fish fed on dietary $K$. africana fruit meal. The egg size was significantly $(P<0.05)$ different in all the diets.

There was a significant difference $(P<0.05)$ in percentage fertilization and hatchability among the treatments. Diet D3 had the best percentage fertilization $(91 \pm 1.13)$ and percentage hatchability $(89 \pm 0.13)$. The percentage deformity differs among 
Agric. Biol. J. N. Am., 2010, 1(5): 791-795

the treatments, with values ranged from $0.95 \pm 0.1$ to 3.65 \pm 1.42. The highest percentage deformity was recorded in the control diet. The highest percentage survival of larval was obtained in diet D3 $(93 \pm 0.45 \%)$ while the lowest was in diet D5 $(80 \pm 1.13)$.

Table 2 Reproductive performance of female $C$. gariepinus fed dietary inclusion of $K$. africana

\begin{tabular}{|l|l|l|l|l|l|}
\hline Parameters & \multicolumn{5}{|c|}{ Dietary Treatments $\mathrm{g} / \mathrm{kg}$ feed } \\
\hline & 0 & 50 & 100 & 150 & 200 \\
\hline Fecundity & $93345 \pm 11294^{\mathrm{b}}$ & $69295 \pm 2764^{\mathrm{a}}$ & $82074 \pm 15335^{\mathrm{ab}}$ & $7237 \pm 2855^{\mathrm{ab}}$ & $59904 \pm 480^{\mathrm{a}}$ \\
\hline \% fertilized & $81.00 \pm 9.90^{\mathrm{b}}$ & $90.23 \pm 0.31^{\mathrm{b}}$ & $90.88 \pm 1.03^{\mathrm{b}}$ & $70.07 \pm 13.42^{\mathrm{ab}}$ & $55.19 \pm 7.19^{\mathrm{a}}$ \\
\hline \% hatchability & $75.00 \pm 14.14^{\mathrm{bc}}$ & $86.14 \pm 0.19^{\mathrm{c}}$ & $88.98 \pm 0.13^{\mathrm{c}}$ & $59.82 \pm 13.70^{\mathrm{ab}}$ & $42.81 \pm 3.33^{\mathrm{a}}$ \\
\hline$\%$ deformity & $3.62 \pm 1.42^{\mathrm{b}}$ & $1.35 \pm 0.49^{\mathrm{a}}$ & $0.95 \pm .01^{\mathrm{a}}$ & $1.03 \pm 0.35^{\mathrm{a}}$ & $1.37 \pm 0.21^{\mathrm{a}}$ \\
\hline \% survival & $89.86 \pm 1.34^{\mathrm{b}}$ & $91.25 \pm 0.52^{\mathrm{bc}}$ & $92.84 \pm 0.45^{\mathrm{c}}$ & $90.88 \pm 0.97^{\mathrm{bc}}$ & $80.28 \pm 1.13^{\mathrm{a}}$ \\
\hline Hatching time $(\mathrm{h})$ & $25.83 \pm 0.56^{\mathrm{a}}$ & $25.09 \pm 0.85^{\mathrm{a}}$ & $24.86 \pm 0.44^{\mathrm{a}}$ & $25.68 \pm 0.18^{\mathrm{a}}$ & $24.19 \pm 0.54^{\mathrm{a}}$ \\
\hline Diameter of egg $(\mathrm{mm})$ & $1.50 \pm 0.00^{\mathrm{b}}$ & $1.50 \pm 0.14^{\mathrm{b}}$ & $1.50 \pm 0.00^{\mathrm{b}}$ & $1.55 \pm 0.17^{\mathrm{bc}}$ & $1.65 \pm 0.17^{\mathrm{a}}$ \\
\hline
\end{tabular}

\section{DISCUSSION}

The result of this study shows that dried $K$. africana fruit meal affects the fecundity, hatching rate and percentage survival of $C$. gariepinus. The increased in fecundity of $C$. gariepinus in this study could be attributed to the presence of biflavonoid and xanthone in the plant. These compounds are potent anti-oxidants which are capable of increasing the production of eostrogen, the key hormone involved in the production and maturation of eggs in the ovary.

The egg diameter was largest in the group of fish fed dried $K$. africana fruit meal but there was no significant difference $(\geq 0.05)$ in all the treatments and this has negative effect on the fertilization of the eggs. Some authors however opined that egg diameter is not a good indicator of egg and larval quality (Carillo et al. 1995). In this study, the progeny of the broodstocks fed on diets D2 and D3 survived better than the ones placed on other diets. Since most of the losses in hatchery are recorded at the critical transitional period of moving from endogenous feeding to exogenous feeding, any effort made to improve the quality of the egg will surely equip the fry for survival (Davy et al.1980). Previous study in male C.gariepinus has shows that dried $K$. africana fruit meal improved fertility in male, especially sperm characteristics (Adeparusi et al. $2010)$. The significantly higher $(p<0.05)$ percentage fertilization and hatching observed in the fish fed the dietary $K$. Africana fruit meal agrees with Adewumi et al. (2005) who reported similar results with effect of heated soybean on egg and sperm quality of $C$. gariepinus. Sule and Adikwu (2004) also reported that species of the genus Clarias with larger eggs also have a higher viability and endurance to starvation than those with smaller eggs and that larger female catfish produce larger eggs.
Ogbeche et al. (2002) reported an increased in the Epididymal sperm motility and \% pregnancy in male and female sprague - dawley rats treated with methanol extract of $K$. africana fruit. Although Kim et al. (1998) observed that unknown factors in various medicinal plants might have led to reduction in the number of deformed larvae, similarly, There was reduction in the number of deformed larval in fish fed the dried dietary $K$. africana fruit meal when compared with the fish fed on the control diet. The dissolved oxygen, $\mathrm{pH}$ and temperature estimated during the experiment were within the acceptable range recommended for catfishes (1986).

\section{CONCLUSION}

In conclusion, dietary $K$. africana fruit meal, which improves the reproductive performance of cultured African catfish, C. gariepinus is useful and reliable method for propagating seedling production and rearing strategy. This study established the efficacy of $K$. africana fruit powder as fertility enhancer in $C$. gariepinus brood stock and should be encouraged as it will minimize the dependence on synthetic drugs as fertility enhancing agents. Therefore, future research should focus on the improvement of seedling production technology for different fish by $K$. africana fruit powder, since the main aim of aquaculture is to maximize fish production and this plant has promising pro fertility property which can be exploited in aquaculture

\section{REFERENCES}

Abioye, A.I.R, Duru, F.I.O., Noronha, C.C. and Okanlawon, A.O. (2003). Aqueous extract of the bark of Kigelia africana reversis early testicular damage induced by methanol extract of Carica papaye. Nig.J.Healht and Biomed. Sci 2(2). 81-87.

Adedeji, O.S., Farimi, G.O., Ameen, S.A. and Olayemi, J.B. (2006b). Effects of bitter kola ( Garcinial kola) as 
growth promoter in Broiler Chicks from day old to four weeks old. J. Anim. Vet. Adv.5(3): 191-193.

Adeparusi, E.O., Dada, A.A. and Alale, O.V. (2010). Effect of medicinal plant (Kigelia africana) on sperm quality of African catfish, Clarias gariepinus (Burchell, 1822) broodstock. J Agric Sci 2(1): 193 - 199.

Adewumi, A.A., Olaleye, V.F. and Adesulu, E.A. (2005). Egg and Sperm Quality of the African catfish, Clarias gariepinus (Burchel) Broodstock Fed Differently Heated Soybean- based Diets. Res J Agric Biol Sci $1(1): 17-22$.

AOAC (1997). Association of official Analytical Chemists Official method of analysis $\left(15^{\text {th }} \mathrm{Ed}\right)$ Vol. 1 (K. Heltich Edition), Arlington, Virginia. pp 1832

APHA (1987). Standard Method for the ExaminationWater Wastewater. $17^{\text {th }}$ ed. Washinghton D.C. pp. 1268.

Ayinla, O.A. and Akande, G.R. (1988). Growth response of Clarias gariepinus (Burchell 1822) on silage-based diets.NIOMRTechnical Paper No. 37. Nigerian Institute for Oceanography and Marine Research, Lagos. pp 19

Bagenal, T. (1978). Aspects of fish fecundity. In Ecology of Fresh Water Fish Production. 2nd edn, (Shelby, D. G.,ed.), pp. 101 - 135. Black well: Oxford, London.

Billard, R.J., Cosson, L. W. Crim and Suquet, M. (1995). Sperm physiology and quality. In. Brood Stock Management and egg and larval quality, (eds: Bromage, N. and J. Roberts), Blackwell Sc. Ltd. Osney mead, Oxford, pp 25-52.

Canyurt, M.A. and Akhan, S. (2008). Effect of Ascorbic Acid Supplementation on Sperm Quality of Rainbow

Trout(Onchorynchus mykiss). Turki J Aquatic Sci, 8:171175.

Carillo, M., Sanuy, S., Prat, F., Cerda, J., Ramos, J., Mananos, E and Bromage, N. (1995). Sea Bass (Dicentrachus labrax L). In:

Broodstoxk Management and Egg and Larval Quality, (Eds: Bromage and J Roberts), Blackwell Science, Osmead, Oxford :pp 424

Dada, A.A. and Ajilore, V.O. (2009). Use of ethanol extracts of Garcinia Kola as fertility enhancer in female catfish Clarias gariepinus broodstock. Int $\mathrm{J}$ Fisheries and
Aquaculture 1 (1):1-5.

Davy, F.B and Chouinard, A (1980). Induced Breeding in S.E. Asia. The International Development Research Centre. Ottawa, Canada: 1277 - 1285.

Fagbenro, O.A. and Adebayo, O.T. (2005). A review of the animal and aquafeed industries in Nigeria. In: A synthesis of the formulated animal and industry in subSaharan Africa. Pp. 25 - 36. (Moel, J. and Halwart M editors). CIFA Occasional paper No. 26, FAO, Rome, $61 \mathrm{pp}$.

Gill, L.S. (1992). Ethnomedical uses of plants in Nigeria. Uniben Press, Benin City. pp: 143

Kim, D.S., Noh, C.H., Jung, S.W. and Jo, J.Y. (1998). Effect of obosan supplemented diet on growth, feed andversion ratio and body composition of nile tilapia Oreochromis niloticus. J. Aquacul. 11: 83-90.

Moses, B.S. (2006). Fisheries and Ecotourism: A Tool for National Development. Proceedings of the Fisheries Society of Nigeria (FISON) (Enim, U.M., E.I. Chukwu; P.O. Ajah; D.A. Aina- Abasi and F.M. Nwowu ed.). pp 412

Ogbeche, K.A., Ogunbiyi, Y.O. and Duru, F.I.O. (2002). Effect of Methanol extract of Kigelia africana on Sperm Motility and Fertility in Rats. Nig J Health and Biomed Sci, 1 (2): 113-116.

Owolabi, O.J. and Omogbai, E.K.I. (2007). Analgesic and anti-inflammatory activities of the ethanolic stem bark extract of Kigelia africana. Afr. J. Biotechnol. 6 (5) :582-585.

Stahl, E. (1988). Thin layer chromatography. Springer Verlag, $2^{\text {nd }}$ Edition, New York, 265-285.

Sule, O.D and Adikwu, I.A (2004). Effect of broodstock size on egg and the African catfish, Clarias gariepinus under laboratory conditions. J Aquatic Sci, 19(1): $1-4$.

Viveen, W.J.A.R., Richter,C.J.J., van Oordt,P.G.W.J., Janssen, J.A.L. and Huisman,E.A. (1986). Practical Manual for the culture of the African catfish (Clarias gariepinnus). Ministry of foreign affairs of the Netherlands, Agricultural University of Wageningen and University of Utrecht, Hague. pp 93.

Zar, J.H (1996). Biostatistical analysis. $3^{\text {rd }}$ Edition. PrenticeHall, Upper Saddle River, New jersey, US: pp 383 